\title{
Examining Students perspectives on the Impact of Formative Assessment on Teaching and Learning; Abu Dhabi Private Schools as a Case Study
}

\author{
Mohamad Ezzat Alkutich \\ British University, Dubai
}

\begin{abstract}
Assessment is the process of gathering evidence of students' knowledge, skills and attitudes. Assessment for learning plays a significant role in improving students learning, and the literature is full with academic studies about the importance of this sort of formative assessment. However, less research is done about students' perspective on the impact of formative assessment on their learning. This paper aims to explore students' perceptions about the impact of formative assessment on teaching and learning. The population of this study is 207 participants; 7 teachers and 200 students from one of the private schools in Abu Dhabi of the United Arab Emirates. The methodology that used in this study is mixed of qualitative and quantitative approaches. A focus discussion group was used as a tool of a qualitative methodology in this study, beside the questionnaires is used as well for this sake. The research question is; what do students believe about the impact of the formative assessment on their learning?

The findings of this study shows that teachers and students give less importance to formative assessment techniques as it is expected. Thus, teachers and students need to be trained to know about the importance of formative assessment strategies and techniques. Moreover, students need to be assessed by more interactive tools of assessment based on students interests and differentiations, because when knowing the cognitive approach and learning style of the students, teachers can provide effective feedback that help students comprehend their learning contents, goals, expectations and self-assessment. Besides, this study provides some helpful formative assessment techniques and strategies to assist teachers, students and parents to have a good understanding of the effective implementation of these tools of assessment for learning.
\end{abstract}

\section{INTRODUCTION}

Assessment is defined as the process of collecting evidence of learner's knowledge, skills and attitude toward the subject (p.3). How to conduct this assessment and the reasons for doing this assessment are vary (Dudley \& Swaffield, 2008). Research found that assessment should be done for improving students learning which means it should be assessment for learning not assessment of learning (Harlen, 2000, p.112). Therefore, there is an urgent need for reforming and changing the traditional use of assessment (Qassim, 2008). This piece of research aims at reforming the use of assessment, namely, the use of formative assessment. Hence, practice-based research is carried out aiming for the betterment use of assessment in educational. The limitation of this study is that it is based on the findings of exposing the views of students only, thus, other researchers are recommended to examine the believes of teachers in this regard, as teachers influence students' views (Franke, Fennema, \& Carpenter, 1997).

Examining student's perspectives on the influence of assessment for learning on the quality of their learning is significant (Ramsden, 1997). To give a clear picture of the strategies and tools of assessment for learning that has practised in schools, a focus discussion group is used as a tool of a qualitative methodology in this study, beside the questionnaires. The goal of this research is to give an answer for this research question: (1) what do students believe about the impact of the formative assessment on their learning?

\section{STATEMENT OF RESEARCH PROBLEM}

The reviewed literature covers lots of studies about the importance of assessment on learning. However, only few of these studies walk around the notion of formative assessment from the viewpoints of students themselves. This study aims to determine the impact of formative assessment from the views of students. 


\section{Purpose of the Study and Research Questions}

The purpose of this research is to present the views of students of Abu Dhabi private secondary schools on the importance of assessment for learning. There is one research question:

$\square$ What do students believe about the impact of the formative assessment on their learning?

\section{Hypothesis}

The main hypothesis of this study is that students have knowledge about the basic understanding of the importance of assessment on their learning. Moreover, students would be willing to share their experiences in this regard.

\section{Limitations and Delimitations of the study}

There are few studies that focus on the effectiveness of formative assessment on students learning and achievements, but fewer studies focus on the viewpoints of students. However, so far, there is no academic research is done based on students perspectives in the Arabic world as I know. Moreover, the population of this study comes from one secondary school in Abu Dhabi, so this would affect generating the results of this study.

\section{Methodology}

The methodology that used in this study is mixed of qualitative and quantitative approaches. A focus discussion group was used as a tool of a qualitative methodology in this study, beside the questionnaires is used as well for this sake. The population of this study is 207 participants; 7 teachers and 200 students from one of the private schools in Abu Dhabi of the United Arab Emirates.

\section{The Significance of This Research}

Several academic studies have revealed that assessment plays a significant role on students learning, most of these researches come from theoretical background, and some of them focused on exam results analysis, but fewer studies focused on the perspectives of teachers and students viewpoints. So, the significance of this study that it tries to cover one of these two missing main players of education. This study aims to discover students' views and experiences about the importance of formative assessment on their learning. Moreover, it recommends other researchers to do more research and studies on teachers' viewpoints about the formative assessment use and effectiveness.

\section{THEORETICAL FRAMEWORK}

\section{Definitions of Formative Assessment}

Researchers depict that assessment needs to be used for improving students learning not for testing their learning as it is proved by many researchers that formative assessment increase the quality of learning (Wiliam, Lee, Harrison \& Black, 2004). Assessment for learning is defined as it is the (Van De Walle, Karp, 2013) define formative assessment as a tool of discovering how much students learn in order to aid teachers to plan the next lesson accordingly.

\section{Techniques and Strategies of formative assessment}

The concept of assessment and its impact on students' learning has attracted the researchers for 30 years (i.e Crooks, 1988; Black \& Wiliam, 1998).

Some of these studies focused on providing strategies and techniques that help teachers when assessing students' learning. Such as, giving oral questions to students while learning a topic, this technique helps for continuous assessment for learning (Cauley \& McMillan, 2010). Other researchers, found that teachers and students appreciate highly the performance test besides the official observation more that the oral question and unstructured observation (Kyriakides \& Campbell, 1999). Likewise, other studies stressed the importance of assessment for learning techniques. Such as, providing students with clear learning objectives before teaching take place. (Cauley \& McMillan, 2010). In his study, Clark suggested a list of strategies and techniques of formative assessment that help in engaging students in the teaching and learning process with reflective and critical thinking and problem solving based learning (2010). The list of these suggested techniques includes; higher order question, feedback as comments on students work, verbal feedback sharing learning objectives, sharing assessment criteria, self-assessment, peer assessment.

\section{The use of feedback in formative assessment}

Feedback provided by teacher to students is one of the most significant tools of assessment for learning; it might be given by questions or even by peer assessment. Moreover, when researchers give a definition to formative assessment they link it with the provided feedback by teacher that improves the quality of learning (Sadler, 1998). Likewise, formative assessment is defined by Cauley and McMillan (2010) as a process of collecting evidence of students 
learning in classroom when teachers modify their teaching according to the provided feedback (Nicol \& MacfarlaneDick, 2004). However, Sadler (1998) Stressed that the use of feedback is not an easy process, because we will not get the fruits of this feedback if we do not train students in how to understand and explain the provided feedback, and how to respond to it.

\section{The formative use of students 'errors}

Students` errors are not something makes students feel ashamed about, these errors should be dealt with as an opportunity to improve students learning, when teachers check students work and listen to their answers, this gives both teacher and student an opportunity to know the weaknesses of students, so the teacher modifies his or her teaching strategies and techniques accordingly. Thus, when students know their weaknesses and errors, they will know eventually what they need to do in order to work to their full potential (Cauley \& McMillan, 2010). Therefore, Gagatsis and Kyriakides in their research found that students 'errors can be used as a means for improving learning (2000). Moreover, it is important that teachers' future decisions about their teaching and students learning start from the pupils 'errors (Desforges, 1989).

\section{METHODOLOGY}

For the sake of study, a mixed methodology approach is used. A focus discussion group is nominated from 7 teachers of different subject to provide the researcher with the formative assessment techniques and strategies that they used in classroom, and to give their opinions on the questionnaires. Moreover, questionnaire for exploring students "perceptions about the impact of formative assessment tools was developed. The questionnaire includes two sections. In the first section questions about the participants' demographics (gender, and class). However, in section two, 44 statements for students agreement or disagreement on Likert scale of 4-point ( 1 =strongly disagree, $4=$ strongly agree). In the first group of these statements, the purpose of the formative assessment was asked in 10 statements. The second group focused on the use of the strategies and techniques of formative assessment, this group included 8 statements. In the third group there were 6 statements about the use of students results and errors in the formative assessment. The forth group had 20 statements asking about the role of (students, teachers, and parents) in the formative assessment.

The questionnaire was directed by the 200 pupils for 30 minutes during school time with the help of their teachers who were members of the focus discussion group. The participants were secondary school students, aged 12-15.

\section{Sample Selection}

The population of this study are 207 participants. 200 secondary school students and 7 teachers, all students and teachers come from one international school in Abu Dhabi, these teachers and students cover different subjects (English, Arabic, Maths, Science, History, Spanish and Islamic Studies)

\section{Data Collection}

Data of this piece of research is collected by questionnaires designed and sent by Survey Monkey Website to all students and teachers. Each teacher will guide his/her students to answer the questionnaires in the school lab.

\section{Data Analysis}

The findings of this research is analysed by Survey Monkey Website, in which the questions are divided on units as shown in the five presented chains.

\section{Research Validation and Reliability}

In order to have strong validation, triangulation and peer review is hired (Creswell, 2013). Moreover, a variety of academic research is used for the triangulation. Besides, expert review will be used to evaluate research procedures.

\section{Ethical Considerations}

The questionnaires contain personal questions, and the answer on these questions based on self-reflection of the participants, thus, the researcher will keep the data of participants secret so they feel comfortable in revealing their views honestly (Merriam, 2009).

\section{RESULTS}

The findings of this study as it is shown in (Figure 1) present the correlation between particular statements of students' belief and the practice. These relationships offer signs about how specific factors influence the students 'views about formative assessment. As a result of these relationships of these variables in (Figure 1) open the space of discussion for five distinguished chains. 


\section{Chain 1}

This implicative chain stresses the involvement of parents in the process of the formative assessment. The teachers 'practice of sharing with parents or discussing with them the procedures of teaching and learning of their kids, either before (S10a: do your teacher call your parents for a discussion before the assessment?) or even after the assessment (S10b: do your teacher call your parents for a discussion after the assessment?)

Involving parents in these discussions minimize the gap between the teacher and students and their parents, so this assures that there will be no missing information regarding students learning. It is as well; motivate students for more participation in the assessment process, by providing them with the criteria of this assessment and the expectation of the teacher. (S19: do you make a personal check list in order to assess yourself before the assessment?) And also, by adding comments on the corrected work, in order to know what went well (S3: On your corrected work, do you make comments that inform you what you have done well?). Moreover, the sharing with parents the assessment process before the assessment influences the use of differentiation (T18: Do your teacher after an assessment give different activities based on your level?

\section{Table 1}

Percentages of students ${ }^{\text {ee }}$ answers to the statements of the 1st implicative chain

\begin{tabular}{|l|l|l|l|l|l|}
\hline & $\begin{array}{l}\text { No } \\
\text { ans } \\
\text { wer }\end{array}$ & $\begin{array}{l}\text { er } \\
\text { ly }\end{array}$ & $\begin{array}{l}\text { Rare } \\
\text { e }\end{array}$ & $\begin{array}{l}\text { Of } \\
\text { te } \\
\text { n }\end{array}$ \\
\hline $\begin{array}{l}\text { Does your teacher call } \\
\text { your parents to discuss } \\
\text { before the assessment? }\end{array}$ & 5,5 & 50,3 & 21,1 & 14,6 & $\begin{array}{l}8, \\
4\end{array}$ \\
\hline $\begin{array}{l}\text { Does your teacher call } \\
\text { your parents to discuss } \\
\text { after the assessment? }\end{array}$ & 4,2 & 31,5 & 25 & 25,3 & 14 \\
\hline $\begin{array}{l}\text { Do you make a } \\
\text { personal check list in } \\
\text { order to assess yourself } \\
\text { before the assessment? }\end{array}$ & 4,2 & 40,3 & 24 & 17,5 & 14 \\
\hline $\begin{array}{l}\text { On your corrected } \\
\text { work, do you make } \\
\text { comments that inform }\end{array}$ & 1,3 & 39,9 & 22,4 & 21,8 & 14 \\
\hline
\end{tabular}

\begin{tabular}{|c|c|c|c|c|c|}
\hline $\begin{array}{l}\text { you what you have } \\
\text { done well? }\end{array}$ & & & & & \\
\hline $\begin{array}{l}\text { Does your teacher after } \\
\text { an assessment give } \\
\text { different activities } \\
\text { based on your level? }\end{array}$ & 3,2 & 46,4 & 22,1 & 20,8 & $\begin{array}{l}7, \\
5\end{array}$ \\
\hline 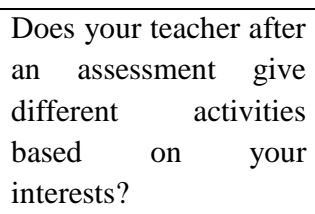 & 3,6 & 45,8 & 25,6 & 17,2 & $\begin{array}{l}7, \\
8\end{array}$ \\
\hline $\begin{array}{l}\text { Do you discuss with } \\
\text { your teacher his/ her } \\
\text { expectations before the } \\
\text { assessment? }\end{array}$ & 2.9 & 26,3 & 31,8 & 23,7 & $\begin{array}{c}15 \\
, 3\end{array}$ \\
\hline
\end{tabular}

The data revealed from (Table 1) shows some indications about pupils' awareness and practice of formative assessment. Firstly, about one third of students used to practise self-assessment strategies sometimes. Also, the findings show that teachers do not focus on the differentiation while teaching and doing assessments, thus, they should give more attention on differentiation. Moreover, about $50 \%$ of the students said that teaches almost never discuss their expectations with students or even with parents.

\section{Chain 2}

The 2nd implicative chain is dedicated to investigate whether teachers share and discuss assessment criteria and their expectations with their pupils and parents before the assessment (S14: do you discuss with your teacher his or her own expectations before the assessment?). Moreover, this chain focusses on students' errors and its formative use (R5: does your teacher offers to be with you while you are correcting your mistakes?), in this chain as well there is a rom to explore whether or not teachers based their planning of next lesson on students' errors and assessment results (R4: does your teacher uses your errors and interests in planning the next lesson?). Besides, the difficulties of students in learning and assessment for learning have a place of interest in this second chain to see if the teachers clarify from students whether or no they understood their own mistakes. (R3: does your teacher after the test verify whether or not you understood your mistakes?).

As a result of the formative assessment it is important that the teacher provides those students who failed the 
assessment with beneficial knowledge that help them to improve their learning. Such as, planning the next lessons according to the students' needs. (T15: does your teacher change the planning of his/her next lessons based on the areas of weaknesses of the performance of the students in the assessment?).

In addition to these results, in (Table 2) the percentages shown below present students' answers about whether or not their teachers base their teaching on students mistakes, interest and areas of weaknesses, and whether or not teachers used to teach the topics again for more simplification.

\section{Table 2}

\section{Second implicative chain of student's answers and their percentages}

\begin{tabular}{|l|l|l|l|l|l|}
\hline & $\begin{array}{l}\text { No } \\
\text { ans } \\
\text { wer }\end{array}$ & $\begin{array}{l}\text { Neve } \\
\mathrm{r}\end{array}$ & $\begin{array}{l}\text { Rarel } \\
\mathrm{y}\end{array}$ & Some & $\begin{array}{l}\text { Ofte } \\
\mathrm{n}\end{array}$ \\
\hline $\begin{array}{l}\text { Does your teacher } \\
\text { offer to be with you } \\
\text { while you are } \\
\text { correcting your } \\
\text { mistakes? }\end{array}$ & 3,2 & 15,6 & 24,4 & 32,8 & 24 \\
\hline $\begin{array}{l}\text { Does your teacher use } \\
\text { your errors and } \\
\text { interests in planning } \\
\text { the next lesson? }\end{array}$ & 2,9 & 32,8 & 28,6 & 24 & 11,7 \\
\hline $\begin{array}{l}\text { Does your teacher } \\
\text { after the test verify } \\
\text { whether or not you } \\
\text { understood your } \\
\text { mistakes? }\end{array}$ & 3,6 & 35,7 & 30,5 & 21,1 & 9,1 \\
\hline $\begin{array}{l}\text { Does your teacher } \\
\text { change the planning } \\
\text { of his/her next } \\
\text { lessons based on the } \\
\text { areas of weaknesses } \\
\text { of the performance of } \\
\text { the students in the } \\
\text { assessment? }\end{array}$ & 11 & 19,8 & 33,4 & 33,4 \\
\hline
\end{tabular}

\section{Chain 3}

In the third implicative chain at the left side these are most famous formative assessment techniques and strategies that teachers and students used to practise frequently while teaching and learning take place in classroom. The aim of this list is to explore how these techniques are significant for the students in their own point of views. In fact, the list is divided into two groups of statements and questions; one of these two groups is dedicated for the techniques that are related to assessment by tests. In which the questions are divided as, multiple choice test, true and false test, and matching two groups of statement test. On other side, the second group is focused on the techniques and strategies that can be used in the formative assessment process. Such as, assessing by interviews, assessing by projects, assessing by presentation of students work, assessing by group works, assessing by portfolio, peer assessment selfassessment and pre-assessment.

When students prioritize and discriminate between the above mentioned techniques and strategies of assessments regarding their use by the teachers and by their importance for the students. The findings of these studies as presented in (Table 3) show that students appreciate mostly the participation in classwork. Moreover, data shows that students see that tests are more important, this explains the relevant percentage given to this group of techniques, which means that this result comes from the factual experience of the students of what happens in the classroom.

Table 3

Students' belief on the importance of assessment techniques and strategies

$1=$ strongly disagree, $4=$ =strongly agree

\begin{tabular}{|l|l|l|l|l|l|}
\hline $\begin{array}{l}\text { Assessment techniques } \\
\text { and strategies }\end{array}$ & $\begin{array}{l}\text { No } \\
\text { ans } \\
\text { wer }\end{array}$ & 1 & 2 & 3 & 4 \\
\hline $\begin{array}{l}\text { Completion questions } \\
\text { test }\end{array}$ & 5,5 & 14,3 & 29,5 & 29,9 & 20,8 \\
\hline Multiple choice test & 4,2 & 13,6 & 24,7 & 30,5 & 26,9 \\
\hline True - False test & 3,9 & 8,4 & 25,6 & 27,6 & 34,8 \\
\hline Matching tasks test & 7,1 & 14 & 28,6 & 27,3 & 23,1 \\
\hline $\begin{array}{l}\text { Participation in class } \\
\text { work }\end{array}$ & 1,3 & 8,8 & 12,3 & 33,8 & 43,8 \\
\hline $\begin{array}{l}\text { Portfolio as a tool of } \\
\text { assessment }\end{array}$ & 10,1 & 28,9 & 29,5 & 17,2 & 14,3 \\
\hline Homework as a tool of & 3,9 & 8,4 & 20,8 & 38 & 28,9 \\
\hline
\end{tabular}




\begin{tabular}{|l|l|l|l|l|l|}
\hline assessment & & & & & \\
\hline $\begin{array}{l}\text { Project as a tool of } \\
\text { assessment }\end{array}$ & 5,8 & 36,4 & 23,4 & 19,8 & 14,6 \\
\hline $\begin{array}{l}\text { Presentation as a tool } \\
\text { of assessment }\end{array}$ & 6,2 & 27,3 & 28,6 & 23,7 & 14,3 \\
\hline $\begin{array}{l}\text { Peer assessment as a } \\
\text { tool of assessment }\end{array}$ & 7,5 & 18,5 & 26,9 & 30,5 & 16,6 \\
\hline $\begin{array}{l}\text { Self-assessment a tool of } \\
\text { Interview a,4 } \\
\text { assessment ark and }\end{array}$ & 10,7 & 18,2 & 24,4 & 26,9 & 19,8 \\
\hline $\begin{array}{l}\text { Group activities as a tool of } \\
\text { assessment }\end{array}$ & 18,8 & 29,2 & 28,2 & 15,3 \\
\hline
\end{tabular}

According to (Table 3), the findings show that students mostly like participation in class work as a tool of assessment for learning. Likewise, about 66 per cent of students appreciate homework to be considered as a tool of assessment for learning. Moreover, about $50 \%$ of students give high importance to the completion questions test, and about $55 \%$ appreciate multiple choices test. Likewise, almost the same percentage is given to true-False tests, also matching tasks tests are appreciated from $50 \%$ of students. Thus, it is obvious that assessment by test in all its techniques has a significant impact on student's perspectives and practice. However, the data depicts that less appreciation from students is given to the formative assessment techniques and strategies, as the following; about $32 \%$ of the participants liked portfolios as a tool of assessment, and $34 \%$ chosen Project as a tool of assessment. Moreover, about 38 per cent highlighted the importance of Presentation of students work, projects, and reports as a tool of assessment. Besides, about $45 \%$ of students expressed their appreciation to self-assessment, peer assessment and group work and activities as a tool of assessment for learning.

\section{Chain 4}

The importance of self-assessment statement in the questionnaire is shown in the fourth chain. Moreover, the benefits of continuous feedback are presented as well. (P5: Do you feel confident and aware about what you are learning in a particular subject when you are provided with continuous feedback?). Moreover, data shown that there is a relation between the continuous feedback and students' knowledge about the teachers; expectation (S16: do you feel more motivated and engaged when you are provided with instructions about what and how to learn in a particular subject?). Nevertheless, there is a linkage between the continuous feedback with the positive belief of the purpose of assessment (P1: Do you think that Assessment helps you identifying your good skills).

All these given questions and statements in chain 4 are proven that continuous feedback impact positively students 'self-confidence (P7: Do you feel that you are more confidant when frequent feedback provided about your progress in a particular subject). Likewise, continuous feedback influence students' motivation while learning (P9: When feeling not satisfied about the grades that received for your effort in a particular subject, do you feel that you have to try harder?).

\section{Chain 5}

The fifth and last chain contains a list of questions and statements about students' perspective of the importance of understanding the subjects versus grading. (S18: What is more important for you to understand the subject or to get a high grade?). Moreover, the list provided of this chain explores students' views if they consider assessment as a tool for discovering their skills (P1: Do you think that assessment helps you identifying your skills in the taught subject?). Besides, providing students' with information about the assessment helps the students set new learning goals (P8: Do you think when providing with assessment information motivates you to establish new and further goals in learning the taught subject?).

Students seem as well positive regarding the use of errors in the assessment in a formative way. (R1: Do you think that correcting your mistakes in the assessment helps you to understand the subject better?). Also, data appreciate the participation of parents in the formative assessment process by providing the students with comments about this assessment (S11: Do your parents make comments about your corrected works, even if when you get low or high grades?) and regarding the criteria of the assessment, students prefer to have them prior to the assessment as it helps them increase their efforts (S15: Do you prefer to know the criteria of the assessment?)

\section{DISCUSSION}

The data provided from the questionnaire shows that there are implicative relations between the different questions of the questionnaire, quite a few indications come about aspects that might have significant role in applying assessment for learning "formative assessment" in teaching and learning. Firstly, students believe that involving parents 
in the process of assessment of their children has a positive influence on both the teacher and the students. Moreover, when offering parents the opportunity to participate in the assessment can help the students in improving selfassessment performance. Besides, it is appreciated when teachers provide students with assessment criteria and comments on their errors, however, it is highly appreciated when their parents' make comments on assessment criteria and teachers' expectations.

On other side, continuous feedback impact student's learning positively. Continuous feedback when provided, establishes a positive confidence about the purpose of the formative assessment. Continuous feedback as well offers the learners information about what to learn and how to learn. This provided knowledge increase students' intrinsic motivation. In their research, Nicol and Macfarlane-Dick found that the significant feedback influence students' selfassessment inspires peer conversation and comments from the teacher and students about their learning establish the foundations of the perfect practice of formative assessment by clarifying its goals, criteria and standards. It also provides teachers with information about their future planning (Nicol \& Macfarlane-Dick, 2004).

In addition to the aforementioned findings, self-assessment is the source of students' feedback. Thus, it is important to develop their abilities of self-assessment in order to be provided with continuous feedback that benefit their learning. On other confront, feedback should not be provided from teachers only, but also it is important to train students to provide each other with formative feedback about their learning and errors in the assessments and other learning productions. Hattie in his study depicts that formative assessment has a significant impact on students learning only when powerful feedback from students' classmates about their knowledge and misconceptions (2009).

The findings of this study show that students prompt optimistic views about formative assessment. They appreciate the role of formative assessment in discovering the skills that they have and they highlight the positive influence of the formative use of assessment's errors and mistakes, as well as parents 'comments. Thus, students by this effective use of formative assessment techniques are able to set their new learning goals, particularly when they are provided with the assessment criteria and their teachers' expectations. These findings are in agreement with the findings of Cauley and McMillan, as they expressed that showing the students their errors and misconceptions and giving them the directions of how to correct their answers to the task prompt and increase their motivation and encourage them to work harder to their potential (2010).

\section{CONCLUSION}

To sum up, this study aims to present students views on the impact of formative assessment on teaching and learning. Moreover, the purpose of this study is to answer the research question (what do students believe about the impact of the formative assessment on their learning?). Thus, the findings show that students 'views of the importance of formative assessment vary based on the different techniques or strategies. The high percentage given to the assessment by tests techniques and strategies shows that our schools still provide old fashion teaching and learning that based on grading and tests. Thus, teachers and students need to be trained to know about the importance of formative assessment strategies and techniques. Moreover, students need to be assessed by more interactive tools of assessment based on students interests and differentiations, because when knowing the cognitive approach and learning style of the students, teachers can provide effective feedback that help students comprehend their learning contents, goals, expectations and self-assessment (Cauley \& McMillan, 2010).

This study provides a table (Table 6) as a suggestion for helpful use of formative assessment techniques and strategies to assist teachers, students and parents to have a good understanding of the effective implementation of these tools of assessment for learning. 
Table 6

Effective use of formative assessment factors

\begin{tabular}{|c|c|c|}
\hline & Students & Teachers \\
\hline $\begin{array}{l}\text { Parents comments } \\
\text { and feedback }\end{array}$ & Feedback source & $\begin{array}{l}\text { Planning next } \\
\text { actions } \\
\text { differentiation }\end{array}$ \\
\hline $\begin{array}{l}\text { Assessment } \\
\text { criteria }\end{array}$ & $\begin{array}{l}\text { To know teacher's } \\
\text { expectation. } \\
\text { Identify self- } \\
\text { criteria }\end{array}$ & $\begin{array}{l}\text { Clarify their } \\
\text { expectations } \\
\text { To be discussed } \\
\text { with students }\end{array}$ \\
\hline Self-assessment & Feedback source & $\begin{array}{lr}\text { Sharpen } & \text { self- } \\
\text { assessment } & \text { skills } \\
\text { of students } & \end{array}$ \\
\hline $\begin{array}{l}\text { Use of errors and } \\
\text { mistakes }\end{array}$ & $\begin{array}{l}\text { Maximizing } \\
\text { concepts } \\
\text { understanding }\end{array}$ & $\begin{array}{l}\text { Planning next } \\
\text { lessons according } \\
\text { to learners' needs }\end{array}$ \\
\hline $\begin{array}{lr}\text { Strategies } & \text { and } \\
\text { Techniques } & \text { of } \\
\text { assessment } & \end{array}$ & $\begin{array}{l}\text { Classwork } \\
\text { participation }\end{array}$ & $\begin{array}{l}\text { Effective } \\
\text { interaction } \\
\text { learners }\end{array}$ \\
\hline
\end{tabular}

\section{FURTHER STUDIES}

This piece of research as presented earlier focuses on the beliefs of students about the importance of formative assessment on teaching and learning. However, more researches are needed to investigate the beliefs of teachers, because beside students, teachers are key players in the process of teaching and learning.

\section{REFERENCES}

Black, P., \& Wiliam, D. (1998). Inside the black box: Raising standards through classroom assessment. Phi Delta Kappan, 80(2), pp. 139-148. [Accessed 3 December 2016]. Available at: http://ai2-s2pdfs.s3.amazonaws.com/15bc/cadd19dbeb64ee5f0edac90e 5857e6d5ad66.pdf

Cauley, K. M., \& McMillan, J. H. (2010). Formative assessment techniques to support student motivation and achievement. The Clearing House: A Journal of Educational Strategies, Issues and Ideas, 83(1), 1-6. [Accessed 3 December 2016]. Available at: https://pdfs.semanticscholar.org/442e/04cacceeb9afecb5b6 dc52884d69b5adfe5e.pdf

Clark, I. (2010). The development of 'Project 1': Formative assessment strategies in UK schools, Current Issues in Education, 13(3). [Accessed 3 December 2016]. Available at:

https://cie.asu.edu/ojs/index.php/cieatasu/article/viewFile/3 $82 / 102$

Creswell, J. (2013). Qualitative inquiry \& research design: Choosing among five

approaches (3rd ed.). Thousand Oaks, CA: Sage.

Crooks, T. J. (1988). The impact of classroom evaluation practices on students. Review of educational research, 58(4), pp. 438-481. [Accessed 1 December 2016]. Available

at:http://www.mendhamboro.org/cms/lib02/NJ01000391/C entricity/ModuleInstance/638/Crooks_-

_Impact_of_Classroom_Evaluation_Practices_on_Students .pdf

Desforges, C., 1989. Testing and Assessment. Education Matters Series. Continuum Publishing, Co., 370 Lexington Ave., New York, NY 10017-6503.

Dudley, P., \& Swaffield, S. (2008). Understanding and using assessment data, In S. Swaffield (Ed.), Unlocking assessment: Understanding for reflection and application (pp. 105-120), Routledge.

Franke, M.L., Fennema, E., \& Carpenter, T.P. (1997). Teachers creating change. Examining evolving beliefs and classroom practice. In E. Fennema \& B.S. Nelson (Eds.), Mathematics teacher in transition. The studies in mathematical thinking and learning series, pp. 225-282.

Gagatsis, A. and Kyriakides, L. (2000). Teachers' attitudes towards their pupils' mathematical errors. Educational Research and Evaluation, 6(1), pp.24-58. [Accessed 1 December 2016]. Available at: https://www.researchgate.net/profile/Leonidas_Kyriakides/ publication/228408441_Teachers_Attitudes_Towards_Thei r_Pupils_Mathematical_Errors/links/0912f50f12c6c447f80 00000.pdf

Harlen, W. (2000). Teaching, learning and assessing science 5-12 (3rd ed.). London: Paul Chapman Publishing. 
Hattie, K. (2009). Visible learning: A synthesis of over 800 meta-analyses relating to achievement. New York: Routledge

Kyriakides, L. \& Campbell, R.J. (1999). Primary teachers“ perceptions of baseline assessment in mathematics. Studies in Educational Evaluation, 25(2), pp.109-130.

Merriam, S. B. (2009). Qualitative research: A guide to design and implementation. San Francisco: Jossey-Bass.

Nicol, D., \& Macfarlane-Dick, D. (2004). Rethinking formative assessment in HE: a theoretical model and seven principles of good feedback practice. In C. Juwah, D. Macfarlane-Dick, B.

Qassim, J.A.S. (2008). Teachers" perceptions of current assessment practices in public secondary schools in the State of Qatar. Doctoral dissertation. The University of Hull.

Ramsden, P. (1997). The context of learning in academic departments. In The experience of learning: Implications for teaching and studying in higher education, 2, pp. 198 217. [Accessed 2 December 2016]. Available at: http://www.etl.tla.ed.ac.uk/docs/ExperienceOfLearning/Eo L13.pdf

Sadler, D. R. (1998). Formative assessment: Revisiting the territory. Assessment in education, 5(1), pp.77-84. [Accessed 2 December 2016]. Available at: http://dropoutrates.teachade.com/resources/support/5035b2 4fecda6.pdf

Van De Walle, A. J., Karp, S. K., \& Bay-Williams, M. J. (2013). Elementary and Middle School Mathematics: Teaching Developmentally (8 ed.). United States of America: Pearson.

Wiliam, D., Lee, C., Harrison, C. \& Black, P. (2004). Teachers developing assessment for learning: impact on student achievement. Assessment in Education, 11 (1), pp.49-65. 